\title{
Water and the human culture of appropriation: the Vaal River up to 1956
}

\author{
JOHANN WN TEMPELHOFF*
}

\begin{abstract}
There is discernable evidence of the human presence having historically appropriated the 1300 kilometer long Vaal River of South Africa as it extends itself from the Drakensberg Plateau into the arid Karoo region. This hard-working tributary of the Orange River, which was instrumental as a supply of water to the Witwatersrand, in the era of the region's gold mines, has been used by humans in a variety of ways. First it was used as a route of communications, then as a borderline demarcating the territorial spaces of states and colonies. Later it was used for purposes of economic development. In the study the objective is to point towards the manner in which humans have influenced the river and its hinterland, particularly from the nineteenth century, up to the 1950s. The process of appropriation, it is argued, has had a different effect when humans laid claim to the river and its environment for social, economic and political purposes.
\end{abstract}

Keywords: Vaal River, appropriation, missionary history, diamond mining, gold mining, industrial development, water pollution, hydrology, irrigation, cultural history, Orange Free State, Transvaal (Gauteng).

\section{Introduction: Humans, nature and cultural appropriation}

Appropriation, a term encapsulated in the thinking of Veblen on consumption, ${ }^{1}$ has been a prominent point of discussion in cultural sciences in recent years. Whilst cultural appropriation appears to be suspect and subject to criticism, ${ }^{2}$ appropriation, per se, which

* School of Basic Sciences, Vaal Triangle Faculty, North-West University, South Africa.

1 T Veblen, "The beginnings of ownership" in The American Journal of Sociology, 4(3), November 1898, pp. 352-365;

2 T Heyd, "Rock art aesthetics and cultural appropriation" in The Journal of Aesthetics and Art Criticism, 61(1), Winter, 2003, pp. 37-46; JO Young, "Profound offense and cultural appropriation" in The Journal of Aesthetics and Art Criticism, 63(2), Spring 2005, pp. 135-146; D Cuthbert, "Beg, borrow or steal.: the politics of cultural appropriation" (Review of B Ziff and PV Rao (eds.) Borrowed power: essays on cultural appropriation, (Rutgers University Press, New Brunswick, 1997) in Postcolonial Studies, 1(2), 1998, pp. 257-262; P Kulchyski, "From appropriation to subversion: aboriginal cultural production in the age of postmodernism" in American Indian Quarterly, 21(4), Autumn 1997, pp. 605-620. 
implies 'a special capacity to separate ... from nature what human beings find useful and transform it in ways that other species supposedly cannot even imagine', ${ }^{3}$ appears to enjoy qualified acceptance. Perhaps one of the most striking examples of appropriation is found in the manner in which humans, when they settle in specific environments, first appropriate the land and then the available water resources. In combination these two natural resources provide the essential substances required for the cultural dynamics of human settlement processes to clearly come to the fore. Water is a most unusual substance. It shapes our lives, as well as our understanding of the spaces within which we find ourselves - even if it only provides a sense of observational dimensionality or depth of field, or maybe an awareness of scale. This is more than apparent in the case of rivers. In a relatively waterstarved country, such as South Africa, a river is a significant feature in any landscape. Even dry river beds have an intrinsic value. ${ }^{4}$ With perhaps the exception of rugged mountainous landscapes, rivers dominate other natural elements of the land that surround them. We are influenced by the environment in which we live when we, for example, adapt ourselves to local conditions. It is also evident that humans have a tendency to try and subjugate the environment in which they find themselves. This can be done in a number of ways. We construct, deconstruct, direct and redirect the environment to the extent that, at times, it tends to strike back at us in the form of a catastrophe under conditions of natural disaster. History informs us that floods ${ }^{5}$ and droughts ${ }^{6}$ cause severe damage to the structures

3 T Heyd, "Rock art aesthetics and cultural appropriation" in The Journal of Aesthetics and Art Criticism, 61(1), Winter, 2003, p. 37.

4 CJ Andersson, Lake Ngami or explorations and discovery during four years of wandering in wilds of South-Western Africa (Facsimile edition by C Struik, Cape Town, 1987, of the second edition, Hurst and Blackett, London, 1856), pp. 48 and 118.

5 DE Terblanche, CGS Pegram and MP Mittermaier, "The development of weather radar as a research and operational tool for hydrology in South Africa" in Journal of Hydrology, 241(1-2), January 2001, p. 4; K Rowntree, "Geography of drainage basins: hydrology, geomorphology, and ecosystems management" in R Fox and K Rowntree (eds.), The geography of South Africa in a changing world, (Oxford University Press, Cape Town, 2000), p. 403; WJR Alexander, "Floods, droughts poverty and science" in Science in Africa On-Line, September 2001, at http://www.scienceinafrica.co.za/2001/september/floods.htm.

6 See Unie van Suid-Afrika, (Departement van Landbou), Die groot droogtevraagstuk, (Goewermentsdrukkery, Pretoria, 1926) for a perspective on the impact of drought conditions and recommended solution, in the first half of the twentieth century; For more recent perspectives see PD Tyson and CK Gatebe, "The atmosphere, aerosols, trace gases and biogeochemical change in suthern Africa: a regional integration" in South African Journal of Science, 97, March/April 2001, p. 106; IPS, "Drought in Kenya: A preventable disaster?" in Mail \& Guardian (Print edition) 2004.07.19 at http://archive. mg.co.za/MGArchive/FrameSet.asp?xhitlist $q=$ floods $\& \mathrm{f}=\mathrm{xh}$ itlist\&xhitlist $\mathrm{x}=$ Advanced\&xhitlist $s=$ contents $\& x$ hitlist $d=\& x h i t l i s t ~ h c=\& x h i t l i s t ~ x s l=x h i t l i s t$. xsl\&xhitlist $v p c=$ first\&xhitlist sel=title\%3Bpath\%3Brelevance-weight $\% 3$ Bcontenttype\%3Bhome-path\%3Bhome-title\%3Btitle-path\$vid=MailGuard:MailGuardView\& npusername=MailGuard\&nppassword=MailGuard. 
and textures of human societies. The extent to which nature had been subverted and manipulated by humans, then forms the bottom line on the balance sheet of environmental and cultural conservation.

Despite their imminent threat, rivers as natural features of the landscape are more than often subjugated to the whims of humankind. The process of appropriation, transforming a natural feature of the land, is as old as orderly human society.

In this discussion attention will be given to the manner in which the Vaal River, a tributary of the Orange River, was used by humans up to the 1950s. In the process of contemplating appropriation, from an environmental perspective, it is desirable to allow nature as crucial role player in the process of historical discourse to maintain a status of dominance in its own right. The interface between nature and human culture is noted for different forms of appropriation. When appropriation is based on the physical exploitation of the natural environment, deterioration follows. Thus, it is important to have in place a responsible sense of intellectual awareness, to secure a useful balance between use and abuse, ownership and custodianship. Aspects of this discourse will be dealt with in greater detail below.

\section{The Vaal River}

The Vaal, which extends over a distance of more than $1300 \mathrm{~km}$ from the Mpumalanga Highveld in the east, to the arid Kalahari environment in the west, has played an extraordinary role in South African history. It has been used as a communications route for humans and animals moving over large tracts of land in the interior of South Africa. It has also acted as a boundary line between independent states, British and indigenous communities in the multi-cultural society of sub-continental Africa. The Vaal has been described as the hardestworking river in South Africa, ${ }^{7}$ serving the most populous and economically active region in the country. ${ }^{8}$ It has also been described, in more recent times as resembling a sewage pit, in some places. ${ }^{9}$

Despite all its names and descriptions the Vaal River remains a dominant natural feature of the landscape through which it passes. It has since time immemorial shaped the way in which humans look at the

7 TC Robertson, Die riviere van Suid-Afrika (SABC Publication P61/5A, Cape Times Ltd., Johannesburg, 1961), p. 7.

8 J Clarke, Coming back to earth: South Africa's changing environment, (Jacana Publishers, Houghton, 2002), pp. 116, 134-135.

9. E Tempelhoff, "Afval, besoedeling se eindbestemming: die Vaal Rivier? Nee, ,n rioolsloot" in Beeld, 2002.12.12 at http://152.111.1.251/argief/ berigte/beeld/2002/12/12/12/ 1.html. 
landscape and negotiate the manner in which they intend to eke out an existence in a water-stressed region of Africa.

The Vaal River is the northern tributary of the Orange River (also known in the vernacular as the Gariep, or the Grootrivier), ${ }^{10}$ the largest river in South Africa. As is the case with the Orange, it flows from east to west. The Vaal River was formed about 180 milion years (MY) before the present (BP) when the tectonic plates started shifting as Gondwana Land started breaking up to form the continents of Africa and America. ${ }^{11}$ The Vaal, along with the Limpopo and Orange rivers, formed the boundaries of the Cargonian Highlands in the southern African interior before the Transvaal Griqualand Axis started forming some 60 MY BP. This was when the Karoo and Kalahari River were captured to form the Orange River system, of which the Vaal is a tributary. ${ }^{12}$ As a transporter of water and sediments the Vaal River has acted as an agency of substances that shaped the land in times of floods and droughts. Activities of transfer, transport and communication have a direct linkage with the natural history of the Vaal River, but it can also be linked to human history.

\section{A gentle material appropriation: communications}

Some two thousand years ago the Vaal River facilitated human communications between the water-rich environment of the Drakensberg Plateau region, in the vicinity of Lake Chrissie (the land of the ancient Batswa San), and the arid Kalahari. ${ }^{13}$ The Vaal, as was the case with many of its tributaries, formed the passage way through which San communities that had mastered the craft of livestock farming - and then became known as Khoi - moved from the Highveld into the interior of South Africa. ${ }^{14}$ Khoekhoen-speaking people, unlike their ancestors, who had been hunters, gatherers and foragers in arid and

10 AK Cornelissen, Langs Grootrivier: grepe uit die kleurryke geskiedenis van die Noordweste (n.p., n.d.), p. 3; A Sparrman, A voyage to the Cape of Good Hope, towards the Antarctic polar circle, round the world and to the country of the Hottentots and the caffres from the year 1772-1776, Volume II, (Edited by VS Forbes. Translation from the Swedish revised by J and I Rudner, Van Riebeeck Society, Second series No. 7, Cape Town, 1977), p. 120.

11 K Rowntree, "Geography of drainage basins: hydrology, geomorphology, and ecosystems management" in R Fox and K Rowntree (eds.), The geography of South Africa in a changing world, (Oxford University Press, Cape Town, 2000), p. 393.

$12 \mathrm{~T}$ McCarthy and B Rubidge, The story of earth \& life: a southern African perspective on a 4.6-billion-year journey, (Kumba Resources, Struik, Cape Town, 2005), p. 264.

13 I Schapera, "The tribal divisions of the San" in Man, 27, April 1927, p. 71.

14 R Elphick, Khoikhoi and the founding of White South Africa, (Ravan Press, Johannesburg, 1985), pp. 17-19; N Penn, "The Orange River frontier zone, c. 1700-1805" in AB Smith (ed) Einiqualand: studies on the Orange River frontier, (UCT Press, Cape Town, 1995), pp. 42-43. 
semi-aquatic environments, had become familiar with the intricacies of the Iron Age and they formed an avant garde frontier society, transferring the skills of pastoral industry and Iron Age technology to new territories. They were the carriers of an appropriated culture, acquired from southward migrating Bantu-speaking peoples from Central East Africa.

By the end of the eighteenth century the Vaal, in the vicinity of the Harts River - and also where it flows into the Orange River - had become a territory of dynamic cultural interaction. From the southeast came members of a mixed Iron Age and Stone Age tradition. From the south and southwest came people of mixed colonial Asian and African, as well as European descent. The frontier communities of the Kora!, the Griqua and related Khoi groupings settled in many parts, close to water supplies. Here they lived under conditions of selfsustaining subsistence in an arid region. Towards the end of the eighteenth century trekboers (primarily migrant livestock farmers), missionaries, traders and other travellers made use of these passages into the interior of southern Africa. Apart from water supplies, the moisture close to the river, grass-covered banks that could be used for feeding livestock and timber resources for purposes of energy, were valuable environmental resources. ${ }^{15}$ It was however seldom an easy passage across the river. ${ }^{16}$

A notable feature of South African rivers is the fact they seldom have navigable water ways. ${ }^{17}$ The Vaal River is no exception. ${ }^{18}$ However, it depends on the time of year. In the summer months, when it rained a lot, travelling on the river was a lot easier than in the dry winter months (April to August). There have also, historically, been diverse opinions on appropriate vessels for travelling on the river. The Khoi used tree stump vessels for crossing the Orange ${ }^{19}$ - and presumably also the Vaal in the arid areas.

15 HS Gassiott, "Notes from a journal kept during a hunting tourn in South Africa" in Journal of the Royal Geographical Society of London, 22, 1852, p. 138.

16 A Smith, "Report of the expedition for exploring Central Africa" in Journal of the Royal Geographical Society, 6, 1836, p. 399.

17 This observation was already made at the start of the nineteenth century by J BARRow, An account of travels into the interior of Southern Africa Volume II, (A Strahan, The Strand, 1804), p. 332; A recent meta-interpretation for the African continent is P CoLLIER AND JW Gunning, "Why has Africa grown slowly?" in The Journal of Economic Perspectives, 13(3), Summer 1999, pp. 12-3.

18 F Jeppe, "Notes on some of the physical and geological features of the Transvaal to accompany his new map of the Transvaal and surrounding territories" in Journal of the Royal Geographical Society of London, 47, 1877, p. 224; FL Cachet, De worstelstrijd der Transvalers aan het volk van Nederland verhaald, (JH Kruyt, Amsterdam, 1882), p. 334.

$19 \mathrm{E}$ and F Bradlow, (eds), Somerville's narrative of his journeys to the Eastern Cape frontier and to Lattakoe 1799-1802 (Van Riebeeck Society, Series 1, Cape Town, 1979), pp. 81-82.

TD, 2(2), December 2006, pp. 431-452. 
As more people of European descent started moving into the interior a variety of vessels were used for travelling on the Vaal River. We know of Thomas Baines' sailing boat 'under British colours' on the Vaal River near Potchefstroom in September $1850 .^{20}$

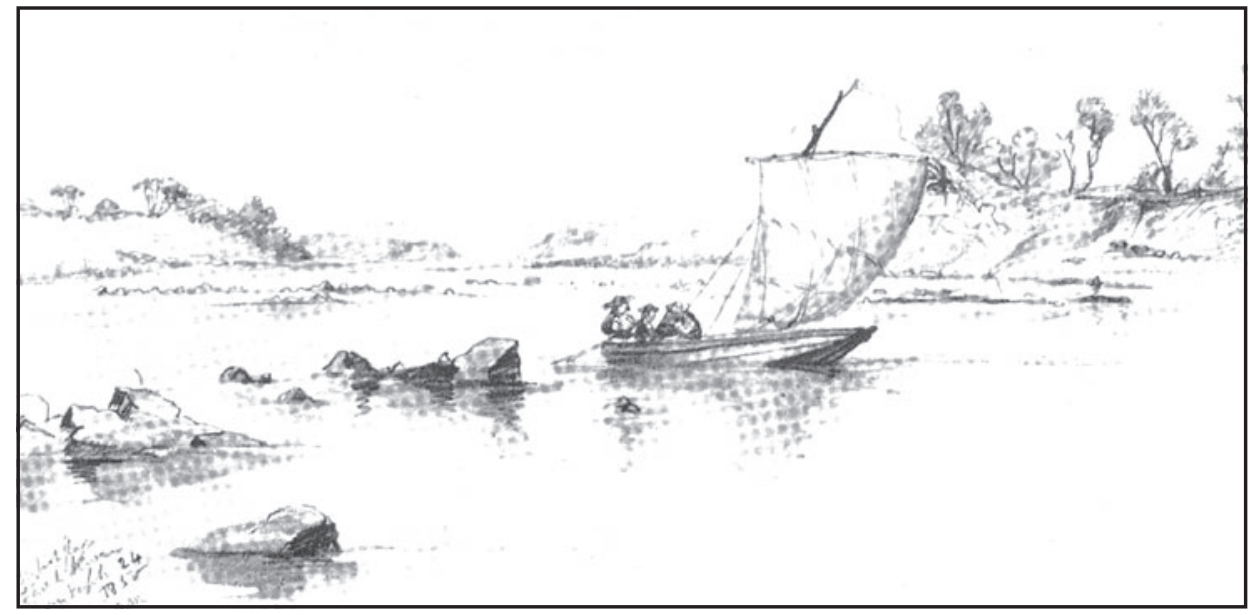

Illustration: Thomas Baines sailing on the Vaal River on 24 September 1850. ${ }^{21}$

Twenty years later the explorer, Karl Mauch, travelled almost $500 \mathrm{~km}$ down the Vaal (from its junction with the Mooi River to Hebron) in a small flat-bottomed vessel (about 3,1m X 1,1m). Mauch was convinced that if some alternations could be done to the course of the river in some parts, it would be possible to travel as far down as Bloemhof. At the time it was deemed strategically desirable to have a water route to settlements on the Diamond Fields. ${ }^{22}$

For the Transvalers it meant that they could use Potchefstroom as regional trading centre, and then travel by boat, to and from the new mining communities in Griqualand West. In the 1880s Sammy Marks considered making use of a flat bottomed boat to transport coal from the Vaal Triangle to the Diamond Fields. Nothing came of the plan. However, recollections of the Tembe, a flat-bottomed vessel that proved to be inappropriate for the waters of the Vaal, is still very much alive in popular historical consciousness. It is a discourse on a visionary plan, for a boat built for travelling on the Vaal, which ultimately

20 T Baines, Journal of residence in Africa 1842-1853, volume 2 1850-1853 (Edited by RF Kennedy, The Van Riebeeck Society, Cape Town, 1964), p. 132. (Entry: 1850.09.24.)

$21 \mathrm{~T}$ Baines, Journal of residence in Africa 1842-1853, volume 2 1850-1853, Illustrations section in book, as well as p. 132. (Entry: 1850.09.24.)

22 F Jeppe, "Notes on some of the physical and geological features of the Transvaal to accompany his new map of the Transvaal and surrounding territories" in Journal of the Royal Geographical Society of London, 47, 1877, pp. 224-225. 
finished up being used in Mozambique. ${ }^{23}$

In the course of the nineteenth century it was more than often a serious undertaking to cross the river. These crossings presented a multitude of problems, as is evident from the writings of travellers..$^{24}$ Little wonder then that in the latter part of the century ferries were positioned at some of the drifts. The construction of bridges to cross rivers in the Transvaal were, to a large extent a direct result of the work of Sytze Wopkes Wierda, a Dutch architect, who had been appointed by the republican government in the 1880 s. It was the era when the improvement of roads and communication in the republic took place at a rapid rate. ${ }^{25}$ However, the major breakthrough came in the 1890 s.

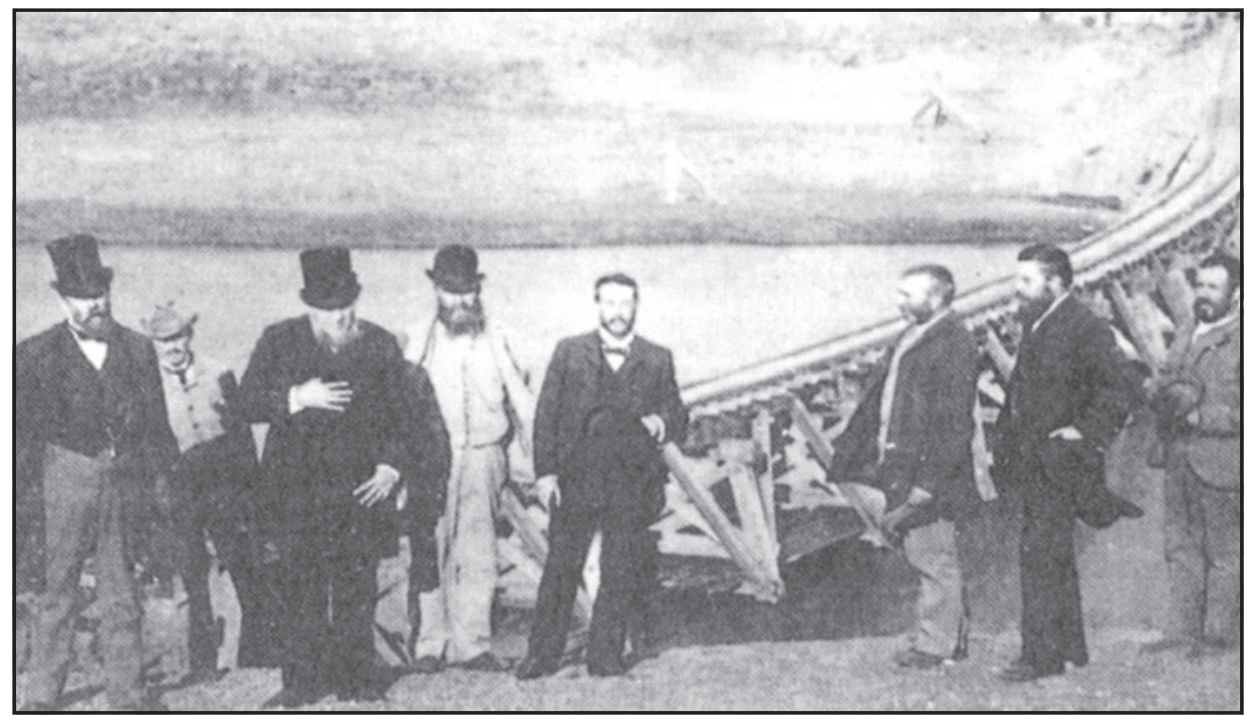

Illustration: In 1892 the railway bridge over the Vaal River at

Vereeniging was taken into use. President Paul Kruger (third from left) and the entrepreneur Sammy Marks (third from right) at one point made plans to transport water in railway carriers to Johannesburg. ${ }^{26}$

23 I am grateful to Prof. Johannes Haarhoff of the University of Johannesburg for the recent information. $\mathrm{R}$ Webster, At the fireside: true South African stories, (New Africa Books (Pty) Ltd, Claremont, 2001), pp. 101-103.

24 A Smith, "Report of the expedition for exploring Central Africa" in Journal of the Royal Geographical Society, 6, 1836, pp. 399-400; P Brooke Simons and M Godby, The life and work of Charles Bell and the art of Charles Bell - an appraisal, (Fernwood Press, Vlaeberg, 1998), p. 36; JA Wahlberg, Travel journals (and some letters) South Africa and Namibia/Botswana, 1838-1856, (Introduced and edited by A Craig and C Hummel. Translated from the Swedish by M Roberts, Second Series no. 23, 1992, Van Riebeeck Society, Cape Town, 1994), p. 82.

25 AJJ Du Preez, Die geskiedenis van Standerton tot 1900, MA, NWU [previously PUCHE], Potchefstroom, 1977), p. 55.

26 Source: Central Archives Repository, Pretoria.

TD, 2(2), December 2006, pp. 431-452. 
The first railway bridge across the river at Vereeniging was built to accommodate the mainline between Cape Town and Johannesburg which started operations in $1895 .{ }^{27}$

Similar developments were at the order of the day in Standerton where, at the same time, the railway line from Natal to Transvaal was opened. ${ }^{28}$ The completion of the Barrage, over a distance of more than $400 \mathrm{~m}$ across the Vaal River, in 1923, opened up the premier bridge-crossing between the Free State and former Transvaal. The single lane bridge across the river formed part of the national road between the Cape and the Witwatersrand which had become the industrial hub of the country. ${ }^{29}$

\section{Intellectual appropriation: religion, security and politics}

The intellectual appropriation of the river had its origins when in 1826 the London Missionary Society's Reverend James Archbell (1798-1866) started working under the Baralong people at Motlhana-wa-Pitse (Platklip) on the banks of the Vaal River, close to the modern Warrenton. ${ }^{30}$

The missionaries promoted the idea of maintaining this contact with the Cape Colony's northern frontier in order to maintain a sense of order, and also secure a route for missionaries to travel from the south into central Africa. Above all, having access to a route along the Vaal River into the interior meant that they were able to work in the interests of the indigenous people who, it was said, were in danger of being subjugated by frontier farmers. ${ }^{31}$ The significance of the river is evident from the travels of Rev. Robert Moffat. ${ }^{32}$ As a feature of the landscape the Vaal River determined the routes of travellers into the interior.

By far the most dynamic role of the river, as a natural water course, is

27 Rand Water Archives (RWA), Klipriviersberg, Souvenir of the opening of the Vaal River scheme by His Royal, Highness Prince Arthur of Connaught, Governor General of the Union of South Africa, 27th July 1923, (Rand Water Board, Johannesburg, 1923).

28 AJJ Du Preez, Die geskiedenis van Standerton tot 1900, pp. 57-59.

29 The Barrage bridge was closed to traffic in the late 1960s.

30 ISJ Venter, "Die rol van die drukpers in die Wesleyaanse Betsjoenasending gedurende die halfeeu 1825-1875" in Historia, 4(3), September 1959, pp. 161-170; Anon., "James Archbell” in WJ de Kock and DW Krüger (reds), Suid-Afrikaanse Biografiese Woordeboek, II, (Tafelberg Uitgewers, Kaapstad, 1972), pp. 12-16.

$31 \mathrm{~J}$ Boas, "The activities of the London Missionary Society in South Africa, 1806-1836: an assessment" in African Studies Review, 16(3), December 1973, pp. 423-424.

32 R Moffat, "Journey from Little Namaqualand eastward along the Orange River, the northern frontier of the colony \&c \&c, in August, 1856" in Journal of the Royal Geographical Society of London, 28, 1858, pp. 174-187. 
to be found in the role it played as a political boundary in the nineteenth century. Van Jaarsveld in his study on the relations between the Orange Free State and Transvaal, ${ }^{33}$ and later in a discourse on controversies pertaining to the river as a borderline ${ }^{34}$ pointed to the pivotal role it played in the era of the Afrikaner republics in South Africa (1830s-1902).

Prior to the arrival of whites, it appears as if the region of the Vaal River, in the vicinity where the Mooi River flows into it, was an area where the Khumalo Ndebele of, Mzilikaze, had settled in the 1820s. Presumably in the face of the approaching white settlers Mzilikazi, a former military commander of Chaka, in the early 1830s started moving in a north-westerly direction. Then, in October 1836 his forces were defeated by the Voortrekkers under the command of AH Potgieter at Vegkop in the Free State. ${ }^{35}$ Consequently Mzilikazi and his followers moved to Zimbabwe.

Subsequent to the clashes with Mzilikazi the Republic of PotchefstroomWinburg came into existence. ${ }^{36}$ Its notable feature was the two small urban conurbations of Winburg (founded 1841) f $^{37}$ to the south and Potchefstroom (founded 1838), ${ }^{38}$ to the north of the Vaal River. The river did not demarcate a boundary. The land between the Vet and the Vaal River had been purchased by Potgieter after deliberations with the African ruler Mancawane. The land to the north of the Vaal River the Voortrekkers claimed for themselves on the grounds that they had defeated Mzilikazi. ${ }^{39}$

After the British annexed the Voortrekker Republic of Natalia in 1842

33 FA van Jaarsveld, Die eenheidstrewe van die republikeinse Afrikaners Deel 1 Pioniershartstogte (1836-1864), (Impala Opvoedkundige Diens, Johannesburg, 1951).

34 FA van Jaarsveld, Vaalrivier omstrede grenslyn, (Perskor, Johannesburg, 1974); For a commentary on this work see J du Bruyn, "FA van Jaarsveld Afrikanerhistorikus en vernuwer" in Historia, 27(1) Mei 1982, p. 59.

35 MC van Zyl, "Die slag van Vegkop" in Historia, 31(2), October 1986, pp. 63-70.

36 FA van Jaarsveld, Die eenheidstrewe van die republikeinse Afrikaners Deel 1 Pioniershartstogte (1836-1864), p. 59.

37 PJ van der Merwe, Die Matabeles en die Voortrekkers in Argiefjaarboek vir SuidAfrikaanse Geskiedenis, 49(2), 1986, (Staatsdrukker, Pretoria, 1986), pp. 278-280; PE Raper, New dictionary of South African place names, ([1987], Second edition, Jonathan Ball Publishers, Johannesburg and Cape Town, 2004), p. 406.

38 FJ Potgieter, Die vestiging van die blanke in Transvaal (1837-1886): met spesiale verwysing na die verhouding tussen die mens en die omgewing in Argiefjaarboek vir Suid-Afrikaanse Geskiedenis, 21(2), 1958 (Staatsdrukkery, Pretoria, 1959), p. 34.

39 FJ du Toit Spies, "Herinneringe van Voortrekkers soos aangeteken deur GA Odé: Herinneringe van JP Marais" in Historia, 5(1), Maart 1960, p. 23; J Bergh, "Die Voortrekkers tot ca. 1844" in J Bergh (red.), Geskiedenisatlas van Suid-Afrika: die vier noordelike provinsies, (JL van Schaik, Pretoria, 1998), pp. 124-128; JS Bergh, "Die veranderende grense van 'Transvaal', 1840-1994” in Historia, 41(2), November 1996, p. 12.

TD, 2(2), December 2006, pp. 431-452. 
a sense of mutual distrust set in between the frontiersmen and their British neighbours in Natal. The politics of territorial domination permeated all levels of white society in the Vaal River region. Delegorgue, a French naturalist who visited Potchefstroom in 1843 with the famous August Wahlberg, noted how the British and Transvalers appeared to be at political loggerheads. Personally, he chose to remain aloof of the politicking. This enabled him to describe the river in aesthetic contexts when he wrote:

(The) Vaal River is big and beautiful and full of water, although not very impressive looking at Linequay-Drift (Lindeques Drift) where her life is just beginning. By the time she reaches the lower drift known as Vaater-ValDrift (Waterfall Drift) she has grown beautiful, ample, strong, even frightening. There, where her deep waters sleep in a bed curtained by willows, Vaal River could make poets dream; there she equals in beauty the most beautiful, as she moves a while with dignity, before casting herself, tumbling and foaming and eager to lose her name into the embrace of Groote Rivier. ${ }^{40}$

His fellow-traveller, Wahlberg, on crossing the river, noted how wide it was. He also spotted a 'beautiful land-crab' as well as a quagga in the proximity of the river. ${ }^{41}$

Five years later, in February 1848, the British, under Sir Harry Smith, annexed the Orange River Sovereignty. Rather than lose their independence the trans-Valers then relinquished their claim to the land between the Vaal and the Vet River. ${ }^{42}$

The British annexation had the effect that the Transvalers, who had not been very united, now tended to close ranks and seek closer collaboration to form a united front against the British. ${ }^{43}$ The political tension between Boer and Brit was omnipresent. The Vaal River was a symbol of feelings of animosity.

In 1850 Thomas Baines, like Delegorgue seven years earlier, stood on the banks of the Vaal River and observed beautiful mimosa trees on the banks of the river and how wagons were moving through the drift.

Also he noted with a sense of disappointment how much of the wildlife

40 F Webb, SJ Alexander and B Guest, Adulphe Delegorue's travels in Southern Africa, II, (Killie Campbell Africana Library and the University of Natal Press, Durban and Pietermaritzburg, 1997) p. 167.

41 JA Wahlberg, Travel journals (and some letters) South Africa and Namibia/Botswana, 1838-1856, (Introduced and edited by A Craig and C Hummel. Translated from the Swedish by M Roberts, Second Series no. 23, 1992, Van Riebeeck Society, Cape Town, 1994), p. 65.

42 FJ du Toit Spies, "Herinneringe van Voortrekkers soos aangeteken deur GA Odé: Herinneringe van JP Marais" in Historia, 5(1), Maart 1960, p. 25.

43 DJP Haasbroek, "Potchefdstroom se status en verhouding tot die res van die Voortrekkergemeenskap" in Historia, 1(3), Februarie 1957, pp. 239-254. 
that Cornwallis Harris had described on the Vaal River, two decades earlier, ${ }^{44}$ was now absent. This state of affairs he ascribed to the fact that firearms, used by the Boers, had been used to hunt down the wildlife. ${ }^{45}$ The political discourse of culture acted as a catalyst in his states of awareness, whilst reflecting on the river and its environment. It was a subsidiary of his (expanding) spatial awareness.

In 1852 the Transvalers and the British signed the Sand River Convention. ${ }^{46}$ The Vaal River now was a distinct boundary line. The British gave the undertaking that they would not annex the area to the north of the river. ${ }^{47}$ At the time of the signing of the treaty, Sanderson passed through the Vaal into the Transvaal where, in Potchefstroom, he became very much aware of the effect that the treaty had on the psyche of the Transvalers. He noted that they were jubilant and there were festivities in the village of Potchefstroom, as the residents were informed that forthwith the British would leave them at rest. ${ }^{48}$ Clearly the culture of politics again reduced the river and its environment to a line on the landscape demarcating a cosmetic division between two societies that were very similar in most cultural contexts.

The political appropriation of the Vaal River led to very fixed discourses of real and imagined territorial struggles for power. On the northern banks of the Vaal the republican burghers were determined to maintain their independence of British authority. Supporters of the British, on both sides of the river, were convinced that it was only a matter of time before the trans-Vaal territory would be brought under British control. The Free Staters themselves appeared to be less perturbed by the new borderline. Instead, they anticipated a general improvement in their way of life. Ironically, apart from the fact that that the new borderline tended to strain relations between political-minded people, it clearly affected trade. The Transvalers were vulnerable. They

44 See WC Harris, Narrative of an expedition into southern Africa, during the years 1836, and 1837, from the Cape of Good Hope, through the territories of the Chief Moselekatse, to the Tropic of Capricorn, with a sketch of the recent emigration of the Border colonists and a zoological appendix, (The American Press, Bombay, 1838), pp. 267-275.

45 T Baines, Journal of residence in South Africa 1842-1853, (II, 1850-1853), (Van Riebeeck Society, 45, 1964, Edited by RF Kennedy. Cape and Transvaal Printers, 1964), Cape Town, pp. 54-55.

46 Die Konvensie van Sandrivier, 17 Januarie 1852 in FA van Jaarsveld (ed.), Honderd basiese dokumente by die studie van Suid-Afrikaanse geskiedenis 1648-1961, (Nasou Beperk, Elsiesrivier, c. 1971), pp. 91-93.

47 FB Fynney, "The geographical and economic features of the Transvaal, the new British dependency in South Africa" in Proceedings of the Royal Geographical Society of London, 22(2), 1877-1878, p. 115.

$48 \mathrm{~J}$ Sanderson, "Memoranda of a trading trip into the Orange River (Sovereignty) Free State, and the country of the Boers, 1851-1852" in Journal of the Royal Geographic Society of London, 30, 1860, p. 242.

TD, 2(2), December 2006, pp. 431-452. 
relied on strategic supplies of goods such as gunpowder, lead, coffee, sugar and domestic and farming utensils from itinerant and resident traders with strong links to the coastal ports of Natal, and the Cape Colony. There was clearly a grey area in which politics played a secondary role to the demand of everyday consumer goods. These items had to be conveyed across the Vaal River, a natural obstacle in the communications routes criss-crossing the interior of the future South Africa.

The political polarisation tended to be detrimental to the advancement of cultural activities that were aimed at stimulating the quest for knowledge of an almost unknown frontier zone. ${ }^{49}$ For example, in 1865 Anderson, an explorer who had located the origins of the Vaal River at Klipstapel and Lake Chrissie, was prevented from conducting his researches. The Transvalers, as was also the also case with some of the local African population, were suspicious of everything foreigners surveyed. ${ }^{50}$ For many years there had been attempts at determining the origins of the Vaal River. ${ }^{51}$ The distrust with which local residents viewed Anderson was symptomatic of political discourses of exclusion that proved to be detrimental to disclosures of discoveries, on one of the major waterways of the Transvaal. It hampered efforts aimed at a better understanding of the Vaal River. Ironically this was at a time when Alexander McCorkindale's New Scotland settlement scheme, ${ }^{52}$ to promote industry and higher European population densities, was initiated with the blessing of President MW Pretorius and his government. ${ }^{53}$ The New Scotland settlement was not very successful, but over an extended period of time its pioneering efforts opened the way for the economic growth of the Eastern Transvaal (currently Mpumalanga) region.

49 See Harris description of the origins of the Vaal in the 1830s in WC Harris, Narrative of an expedition into southern Africa, during the years 1836, and 1837, from the Capoe of Good Hope, through the territories of the Chief Moselekatse, to the Tropic of Capricorn, with a sketch of the recent emigration of the Border colonists and a zoological appendix, (The American Press, Bombay, 1838), p. 273.

50 AA Anderson, "Notes on the geography of South Central Africa, in explanation of a new map of the region" in "Proceedings of the Royal Geographical Society and monthly Record of Geography, New Monthly Series, 6(1) January 1884, p. 20.

51 A Smith, "Report of the expedition for exploring Central Africa" in Journal of the Royal Geographicaphical Society, 6, 1836, p. 406.

52 David Forbes, a relative of McCorkindale, who was on a hunting expedition in the interior, is said to have first come across the area that was later to become known as New Scotland. He was impressed by it because the landscape reminded him of Scotland. See HM Jones, A biographical register of Swaziland to 1902, (University of Natal Press, Pietermaritzburg, 1993), p. 230. The temperate climate and particularly the abundant water supplies in the region undoubtedly played a role in the decision to start the settlement. See F Jeppe, Transvaal book almanac and directory for 1877, (P Davis and Sons, Pietermaritzburg, 1877; Facsimile reprint, State Library, Pretoria, 1976), p. 30.

53 AN Pelzer, "Alexander McCorkindale en sy skemas, 1864-1866" in Historia, 15(1), March 1970, pp. 6-23. 


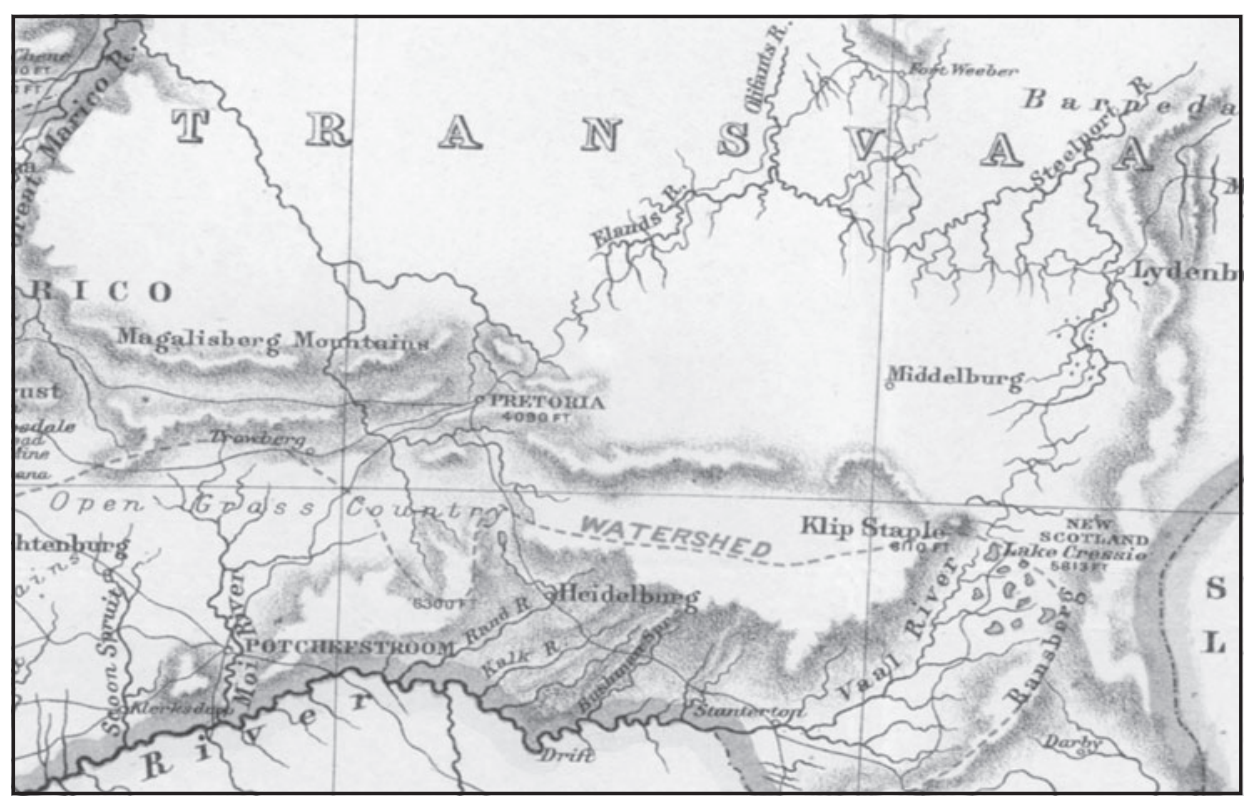

Illustration: Part of Anderson's map of the 1880s, pointing to the origins of the Vaal River. He had originally conducted his exploratory work on the origins of the river in the 1860 s. $^{54}$

To what extent the political appropriation of the Vaal River as boundary could be shaped, was evident when in the late 1860s the Free Staters and the Transvalers were at loggerheads about the boundary line of the Free State. The Transvalers maintained that the Wilge River was the most southern branch of the Vaal River. They were eager to have this area demarcated at the boundary between the Free State and the Transvaal. The government of the Free State, in turn, was of the opinion that the boundary was the Liqua or Kapok River. In an attempt to address the issue the two sister republics invited Governor RW Keate of Natal to act as intermediary. Keate chose a medium between the two states and declared Gansvlei, a small river on the northern extremity of Natal that flowed into the Klip River, the border. From there it extended up to the point where the Klip flowed into the Vaal River. ${ }^{55}$

54 Map accompanying AA Anderson, "Notes on the geography of South Central Africa, in explanation of a new map of the region" in "Proceedings of the Royal Geographical Society and monthly Record of Geography, New Monthly Series, 6(1) January 1884, pp. 19-36.

55 F Jeppe, "Notes on some of the physical and geological features of the Transvaal to accompany his new map of the Transvaal and surrounding territories" in Journal of the Royal Geographical Society of London, 47, 1877, p. 222; JS Bergh, "Die veranderende grense van 'Transvaal', 1840-1994” in Historia, 41(2), November 1996, p. 13. 
Up to the 1890s there were differences between the Transvalers and their Free State neighbours - especially in respect of the right of jurisdiction over islands situated in the Vaal River. ${ }^{56}$ These differences were however minuscule in comparison with the problems that the British created for the Free State and the Transvaal.

In 1871 when the British annexed Griqualand West the region between the Vaal and the Harts River, which the Transvaal had claimed for itself, was lost. President J Brandt of the Free State, who also opposed British claims in a part of the new diamond field, was able to successfully negotiate for compensation for the Free State. However, the Transvalers lost out. They were unable to effectively lay claim to a region, which they were convinced, was originally theirs. ${ }^{57}$

In June 1870 President MW Pretorius entered into an agreement with representatives of a diamond mining company and, with the approval of the Volksraad, gave a private company the exclusive rights to mine for diamonds between the Vaal and the Harts River for at least twenty years. ${ }^{58}$

The agreement was subsequently nullified, but it paved the way for the British take-over of what was to become known as Griqualand West. Admittedly the Transvaal government of MW Pretorius was unable to defend its rights, but it was an unjustified move by the British to annex a region in which the Vaal River was a major feature of the land. The British move was subject to severe criticism by foreign observers. ${ }^{59}$

At the time of the conclusion of the Treaty of London in 1884 the British once again restored a portion of the Western Transvaal to the republican government. ${ }^{60}$ The political appropriation of the Vaal River and its environs up to the 1870s was, to a large extent the cultural creation in the hearts and minds of people. In the face of what was to come, the political manoeuvrings between the British and the republicans was a harmless form of appropriation of the parts of the Vaal River.

56 JS Bergh, "Die veranderende grense van 'Transvaal', 1840-1994" in Historia, 41(2), November 1996, p. 16.

57 F Jeppe, "Notes on some of the physical and geological features of the Transvaal to accompany his new map of the Transvaal and surrounding territories" in Journal of the Royal Geographical Society of London, 47, 1877, p. 219.

58 AN Pelzer, "Vroegste pogings tot industrialisasie in die Suid-Afrikaanse Republiek, Historia, 14(4) December 1969, pp. 235-237.

59 A Aylward, "Dutch South Africa: its hydrography, mineral wealth and mercantile possibilities" in Journal of the American Geographical Society of New York, 15, 1883, pp. 12-13.

60 JS Bergh, "Die veranderende grense van 'Transvaal', 1840-1994" in Historia, 41(2), November 1996, p. 15. 


\section{Economic appropriation of the river}

Since the early settlement of whites in the region the north of the range, the Vaal River and its environs had economic potential. Until at least the mid-nineteenth century, there were small economic activities that posed no environmental threat. For example, travellers into the interior, reported on the salt pans adjacent to the river in the more arid regions. The local salt deposits were mined ${ }^{61}$ and the produce was sold to livestock farmers and hunters who required large quantities of salt. Moreover, at the confluence of the Vaal River, at the Mooi, soapstone was mined and used for pipes, goblets and containers. ${ }^{62}$ Traders visiting frontier settlement in the interior saw the Vaal River as a veritable natural resource that could be exploited for raw materials, such as timber, in barter transactions. ${ }^{63}$

The river and its environment had lots of potential for commercial enterprise, especially in the places where it was fairly easy to cross. At places, such as Parys (founded 1876), Standerton (founded 1878), the mining settlement of Venterskroon (founded in 1889), Bothaville (founded 1893) and Christiana (founded 1895) small urban settlements started flourishing on the banks of the Vaal. ${ }^{64}$ Before the end of the nineteenth century, the hamlet of Parys was an industrious centre where farmers were actively irrigating their lands. At Stander's Drift, further to the east, an urban community started forming on the banks of the Vaal River. Nuclear settlements, of this nature, proved to be conducive to the establishment of better lines of communication between the states and colonies of South Africa in the nineteenth century. ${ }^{65}$

The discovery in 1870 of diamonds at Kimberley and the sudden population growth of what soon became the largest urban conurbation in the South African interior temporarily at the time, had the effect of dwarfing the political significance of the Central Transvaal where politics still determined the way in which the Vaal River was perceived.

61 AA Anderson, "Notes on the geography of South Central Africa, in explanation of a new map of the region" in "Proceedings of the Royal Geographical Society and monthly Record of Geography, New Monthly Series, 6(1) January 1884, pp. 20-21.

$62 \mathrm{~J}$ Sanderson, "Memoranda of a trading trip into the Orange River (Sovereignty) Free State, and the country of the Boers, 1851-1852" in Journal of the Royal Geographic Society of London, 30, 1860, p. 244.

63 Ibid., p. 242.

64 PE Raper, New dictionary of South African place names, pp. 36, 55, 301, 354; CB Coetzee (red.), Delfstowwe van die Republiek van Suid-Afrika, Handboek 7 (Vyfde uitgawe, Staatsdrukkery, Pretoria, 1976), pp. 54, 56; Anon., "A stone from heaven" in Boksburg Historical Association BHA, Newsletter, No. 125, April 2005, p. 2.

65 C Cowley, Schwikkard of Natal and the old Transvaal, (Edited by L Herrman, C Struik, Cape Town, 1974), p. 33.

TD, 2(2), December 2006, pp. 431-452. 
The river's economic and industrial significance soon became paramount. With the rise of Kimberley as an industrial centre came the demand for more water. The Vaal River was a major source of supply. In the years to come it was the valuable water supply of the river that shaped the way in which humans appropriated the river.

\section{Hydrological appropriation}

Already in the 1860s there had been a tendency to dam up water supplies in the Vaal River. Apart from securing the sustainability of small farming operations it also served a strategic purpose. In times of drought, farmers would be forced to trek with their livestock to the banks of the Vaal River until such time that rains once again watered the land and provided grazing for livestock. ${ }^{66}$ By the early 1870 s there were many weirs across the river, south of Potchefstroom and as far downstream as Hebron. ${ }^{67}$ The demand for water storage did not diminish.

By the 1890s the water supplies of the Witwatersrand, where a gold rush of immense proportions was reaching a climax, were severely put to the test. There were numerous problems with polluted water and an inability to cope with the growing water shortages. The republican government tried to get private enterprise to undertake the construction of a pipeline between Johannesburg and the Vaal River. This however did not materialise. The politics of conflict between Britain and the richest gold producing region in the world, at the time, prevented engineering skills from being used to harness the water of the river. ${ }^{68}$

In 1905, shortly after the Anglo Boer War (1899-1902), TN Leslie built a weir in the Vaal River for the supply of water to Vereeniging. ${ }^{69} \mathrm{~A}$ British team had just completed an explorative survey of the Vaal River region. In their report, published in 1904, it was evident that the river presented a number of opportunities for irrigation farming. It could also secure water supplies for industrial purposes. The time was also not right. The former Afrikaner republics of the Transvaal

66 A Aylward, "Dutch South Africa: its hydrography, mineral wealth and mercantile possibilities" in Journal of the American Geographical Society of New York, 15, 1883, p. 16.

$67 \mathrm{~F}$ Jeppe, "Notes on some of the physical and geological features of the Transvaal to accompany his new map of the Transvaal and surrounding territories" in Journal of the Royal Geographical Society of London, 47, 1877, pp. 224-225.

68 JWN Tempelhoff, "On Laburn's 'mystery' query - A prehistory of the Vaal River as water source of the Witwatersrand (1887-99)" in Historia, 45(1), May 2000, pp. 88-117.

69 RL Leigh, Vereeniging South Africa, (Courier-Gazette Publishers (Pty) Limited, Johannesburg, 1968), pp. 57-58. 
and Orange Free State were now British colonies. They shared a common border - the Vaal River. Putting the water of the river to use would have been politically insensitive. Consequently, only after 1910, once the Union of South Africa came into existence, was it possible for the Rand Water Board (founded in 1903) to implement a scheme for the construction of a Barrage, modelled on a benchmark design on the River Nile in Egypt. The project which started in 1915 saw the completion of the Barrage in 1923. For the first time in many years the Witwatersrand had a sufficient supply of water. ${ }^{70}$

Hardly had this project been completed when there were indications that the small river village of Parys would be the site of a comprehensive irrigation scheme. Along the Vaal River, in the vicinity of the town, a container site had to be found for storing up large quantities of water. ${ }^{71}$ A decade later, the Department of Irrigation, at the time of the worldwide economic depression 1930-1933, entered into a partnership with the Rand Water Board and instead started construction work on the Vaalbank Dam, also known as the Vaal Dam. ${ }^{72}$ This, the largest storage dam of its kind in South Africa at the time, was built with two purposes in mind. ${ }^{73}$

Firstly, it had to supply water to the Witwatersrand. Secondly, the water of the Vaal River was now appropriated downstream for the development of the largest irrigation scheme in South Africa between the Vaal and the Harts rivers. The Vaalharts scheme on which work started in 1933, was not only a breakthrough for farming in the country, but it also marked a highpoint in the era of irrigation scheme developments in the country. At the time of its completion in 1938 some 28 000ha of agricultural land was available for irrigation farmers who had started occupying small highly productive farms in the region. ${ }^{74}$

70 JWN Tempelhoff, "Time and the river: observations on the Vaal River as source of water to the Witwatersrand 1903-24" Historia 46(1), May 2001, pp. 247-70.

71 U.G. 14 - 1925 Union of South Africa, Report of the Director of Irrigation for the period 1st April, 1923, to 31st March, 1924, (Government Printer, Cape Town, 1925), p. 9.

72 Rand Water Archives, Rietvlei HQ, Anon., Rand Water Board/Randwaterraad, 19031953, (n.p., n.d., c. 1953), pp. 25-26.

73 LA Mackenzie, Irrigation in South Africa. Addendum: Notes on some of the more important irrigation and multi-purpose schemes and projects in the Union of South Africa, (Typewritten manuscript of departmental bulletin, issued by the Director of Irrigation, Pretoria, c. 1946-1948), pp. 5-8; Also see the Vaal River Development Act, No. 38 of 1934 in JM Murray, WG Hoal, W. Pollack and GN Cross (eds), The Union Statutes: classified and annotated reprint 1910-1947, Volume 12, (Government Printer, Pretoria, 1952), p. 781, a.f.

74 JC Kotze, Die Vaalhartsbesproeiingskema - 'n ekonomiese en sosiaal-geografiese studie, (MA Universiteit van Stellenbosch, 1961), p. 6; LA Mackenzie, Irrigation in South Africa. Addendum: Notes on some of the more important irrigation and multi-purpose schemes and projects in the Union of South Africa, pp. 5-6.

TD, 2(2), December 2006, pp. 431-452. 
By the mid-twentieth century the Vaal was an over-worked river. A variety of plans were afoot to locate alternative sources of water. One of the prime projects engineers identified was the construction of a water supply from the snowy mountains of Lesotho to South Africa. The Oxbow project which was to be kept on hold until the 1980s, paved the way for the development of the Orange River scheme in the late 1950s. By optimally using this water some of the stresses, for supplying water to as far down as the Lower Orange River at Upington, substantially relieved the excessive demand for Vaal River water. ${ }^{75}$

\section{Appropriation for purposes of energy and industrial development}

An important subsidiary of the economic appropriation of the Vaal in the twentieth century was the development of large manufacturing industrial concerns and power generating facilities in close proximity of the river. Although its economic appropriation for the farming sector and domestic consumption was important, over the long term the river's strategic function was to support the production of energy. Since time immemorial, water and energy have gone and in hand. It is only in recent times that we have come to realise that whereas alternative sources of energy can be cultivated, there is no alternative for water. ${ }^{76}$

At the start of the twentieth century Sammy Marks was responsible for turning Vereeniging into the 'Sheffield' of South Africa. ${ }^{77}$ On the banks of the Vaal River the first comprehensive iron and steel factory in South Africa, the Union Steel Corporation (USCO) started with production in $1911 .^{78}$ Many related industries followed, such as Stewarts and Lloyds of South Africa Limited (1927), African Cables (1935) and McKinnon Chain (c. 1938-9). ${ }^{79}$

These developments also had a down side. In order to give substance to Marks' Sheffield-ideal, the coal mining town of Vereeniging was transformed from a popular riverine holiday resort for tourists from

75 JWN Tempelhoff, The substance of ubiquity: Rand Water 1903-2003, (Kleio Publishers, Vanderbijlpark, 2003), pp. 393-397.

76 World Business Council for Sustainable Development (WBCSD), Business in the world of water: WBCSD water scenarios to 2025, (Atar Roto Presse SA, Switzerland, August 2006), p. 9.

77 R Mendelsohn, Sammy Marks: 'The uncrowned king of the Transvaal', (David Philip, Cape Town, 1991), pp. 6, 50-1.

$78 \mathrm{CW}$ Guest, Die ontwikkelingsgeskiedenis van die Unie-Staalkorporasie van Suid-Afrika (USKO), 1911-1996, (MA PUCHO, 1999), pp. 41-47.

79 PJJ Prinsloo (ed.), Die geskiedenis van Vereeniging, (PUCHO, Vanderbijlpark, 1992), pp. 259-260. 
the Witwatersrand at the start of the twentieth century, to a centre where industrial activities were of paramount importance. The local availability of water and considerable deposits of coal, in close proximity of the Witwatersrand, proved to be valuable assets. ${ }^{80}$ In December 1906 the Victoria Falls Power Company entered into an agreement with Vereeniging Estates and the firm of Lewis \& Marks for the exclusive right to build a steam driven power station at Vereeniging. ${ }^{81}$ By 1914 also the Rand Mines Power Supply Co. Ltd, was a major consumer of water from the Vaal River. ${ }^{82}$ Prior to the establishment of the Electricity Supply Commission (Escom, currently Eskom) in 1922, ${ }^{83}$ there were substantial private initiatives at generating electricity from the river. These were increasingly consolidated or phased out to strengthen the capacity of Escom in the development of a national electricity supply grid. This meant that larger water supplies had to be allocated to the electricity utility. In the Vaal River Development Act, No. 38 of 1934, a substantial supply of water from the Vaal River was earmarked for Eskom. ${ }^{84}$ It was used at the Klip power station, near Vereeniging, which was the largest of its kind in South Africa at the time. ${ }^{85}$

Up to 1939 Vereeniging was the only major industrial town in a predominantly rural environment in the Barrage section of the Vaal River. Two new towns were subsequently founded in the region. At Vanderbijlpark, ${ }^{86}$ situated on the Transvaal side of the Vaal River the parastatal, Iron and Steel Corporation (Iscor) of South Africa (founded in 1928), ${ }^{87}$ established a modern factory for the manufacture of flat steel products. ${ }^{88}$

$80 \mathrm{CW}$ Guest, Die ontwikkelingsgeskiedenis van die Unie-Staalkorporasie van Suid-Afrika, p. 51.

81 Ibid., p. 11; SR Conradie and LJM Messerschmidt, A symphony of power: the Eskom story, (Chris van Rensburg Publications (Pty) Limited, Melville, 2000), pp. 29-30.

82 Ibid., p. 7.

83 See the Electricity Act, No. 42 of 1922 in JM Murray, WG Hoal, W Pollack and GN Cross (editorial board), The Union Statutes: Classified and annotated reprint 1910-1947 Volume 5, p. 867-932.

84 See Section 8 of The Vaal River Development Scheme, Act No. 38 of 1934 in JM Murray, WG Hoal, W Pollack and GN Cross (Editorial board), The Union Statutes: Classified and annotated reprint 1910-1947 Volume 12, p. 781.

85 SR Conradie and LJM Messerschmidt, A symphony of power: the Eskom story, pp. 91-92.

86 See RWA985, Chief engineer's report, no. 1691 to the finance and executive committee, 1943.09.14, "Vanderbijl' township".

87 Iron and steel industry Act, No. 11 of 1928 in JM Murray, WG Hoal, W Pollack and GN Cross (editorial board), The Union Statutes 1910-1947: Classified and annotated reprint, Vol. 12, pp. 127-48.

88 For details on the works of Iscor and the implication for the water supply, see RWA File 985, F. Kanthack, Johannesburg - Chief engineer Rand Water Board, Johannesburg, 1942.11.04. 
Production gained momentum, especially after World War II (19391945). Opposite, on the Orange Free State side of the river, the town of Sasolburg was established in 1950 to provide in the housing needs for the first synthetic fuel manufacturing plant in South Africa. ${ }^{89}$

Further downstream, the Vaal River was also increasingly subjected to yielding more water for industrial development. In 1947 the Anglo American Corporation announced that it would be opening up the goldfields of the Orange Free State. ${ }^{90}$

The new gold mining town of Welkom and the neighbouring town of Odendaalsrust (founded in 1899), were soon reliant on water piped from a purification plant on the Vaal River at Bothaville.

Seen against this backdrop, the Vaal River lived up to its reputation as the hardest-working river in South Africa. Specifically in the Vaal Triangle intensive industrial development was responsible for the general decline in the environmental quality of the river's water in the Barrage. This deterioration made the responsible authorities more tolerant of purified effluents flowing into the river from the Witwatersrand region. ${ }^{91}$

Local industries used this secondary water. However, in the face of growing water shortages, ${ }^{92}$ more effective technologies were developed by industry (for example in the field of cooling systems) to reduce excessive water consumption.

\section{A new legislative framework: formalised appropriation}

By the 1950s it was evident that that the secondary and tertiary sectors of industry had appropriated the Vaal River to the maximum. The country was in the midst of one of the longest sustained periods of economic growth. There were indications that this trend would not subside in the near future. The government supported the developments. In an effort to focus the activities of the state more efficiently

89 J Meintjes, Sasol 1950-1975, (Tafelberg, Cape Town, 1975), Chapters 2, 4, 5 and 6.

90 Mining Editor, "Union should start big search for water" in Rand Daily Mail, 1945.09.20; Mining Editor, "Water prospects for future O.F.S. mines" in Rand Daily Mail, 1946.02.14; Correspondent, "Huge irrigation scheme for Free State: work started on £4,000,000 project to dam Vet and Sand Rivers" in The Star, 1947.06.07; Political Correspondent, "Vaal water for O.F.S. goldfields: government takes new powers" in The Star, 1948.02.17; E Oppenheimer, "The discovery of gold in the Orange Free State and its economic effects" in African Affairs, 46(185), October 1947, pp. 220-223.

91 It was only in the late-1960s that proactive measures were taken to limit the flow of effluents, especially from the Witwatersrand, into the Vaal River Barrage. See F van Wyk, (M.Sc., Rand Afrikaans University [currently University of Johannesburg], 2001), p. 15.

92 JWN Tempelhoff, The substance of ubiquity: Rand Water 1903-2003, pp. 222-223. 
the legislative framework within which the country's water supplies had been governed since the era of unification in 1910, was changed. For a start, the department of irrigation, dating back to 1913, was replaced by a department of water affairs. ${ }^{93}$

The Water Act, No. 54 of 1956, which replaced all previous waterrelated acts of parliament, now made provision for direct state control over areas in which water was abstracted, supplied or distributed. The government was now responsible to ensure that water was distributed to all who were legally entitled to make use of the supplies. ${ }^{94}$ In effect it implied that the government had to provide support for the development of sufficient water supplies in a country where industrialisation was peaking. ${ }^{95}$

In the case of the Vaal River the new legislation implied that, like al the major rivers of the country, the Vaal would forthwith be subject to central government control. Industrialisation was uppermost in the minds of the leaders of the state and the private sector. This created a situation which implied that it was an appropriation of water resources (in this case the Vaal) that tended to work to the detriment of sound principles of environmental conservation. Instead of seeking alternatives excessive water consumption, new facilities were summarily created.

One example was the Zuikerbosch water purification works of the Rand Water Board. This facility, a technological achievement of great standing, was basically intended to increase the available potable water for consumers of the Rand Water Board. Issues of constructively dealing with contaminated water, were relegated to the back burner.

The government, in terms of the existing policy and legislative framework, recognised the natural tendency for water to be returned to sources from where it originally emanated. Little consideration was given, in the era of rapid economic growth, to potential alternative strategies of water purification for effective re-use. That would only come much later.

93 Irrigation - and water conservation Act, No. 8 of 1912, in JM Murray, WG Hoal, W Pollack and GN Cross (editorial board), The Union Statutes: classified and annotated reprint 1910-1947, Volume 12, pp. 276-183. The department came into existence in terms of Act 8 of 1912, but only started operations in 1913. See R Bate and R Tren, The cost of free water: the global problem of water misallocation and the case of South Africa (Free Market Foundation, Sandton, 2002), pp. 76-7.

94 JE Scholtens, "Law of property" in HR Hahlo and E Kahn (eds), The Union of South Africa: the development of its laws and constitution, (Stevens \& Sons Limited, London, 1960), p. 599.

95 AR Turton, R Meissner, PM Mampane \& Sereme, A hydropolitical history of South Africa's international river basins. WRC Report No. 1220/1/04. (Water Research Commission, Pretoria, October 2004), p. 378.

TD, 2(2), December 2006, pp. 431-452. 


\section{Conclusion}

The appropriation of the Vaal River, ever since the nineteenth century, was noted for the mild manner in which humans first used the river and its valuable water supply. As the pace of development stepped up, principles of economic appropriation became paramount. Over the long term, these material motives were harmful to the environment. The appropriation of the river thrived on processes that were structured to promote a culture of unbridled consumerism. One example is the growth in the domestic consumption of electricity in these years. It was largely caused by an increase in the use of domestic electrical appliances, manufactured in South Africa. It could be said that modernisation, which implied the use of lots of goods and services, was a very universal development in all parts of the world. This may be the case, but it implies that the price of progress was very high. The human appropriation of the Vaal River bears testimony to this. Scant attention was given to the environmental conservation of a natural heritage asset in a cultural landscape that was rapidly changing the face of South Africa. By the mid-1950s the point of gravity of the Vaal River clearly was in the Vaal Triangle region - South Africa's 'Sheffield'. JP Leslie, the chief engineer of the Rand Water Board, at the start of the decade, warned that the Vaal River Barrage faced imminent deterioration. Steps were necessary to prevent, especially sewage and toxic industrial effluent, from destroying a valuable water source of the country's economic nucleus. ${ }^{96}$ His warnings were prophetic. In the next quarter of a century it was to become apparent precisely how fragile the Vaal River environment had become, as a result of the generally brash appropriation of the country's valuable water resources.

96 JWN Tempelhoff, The substance of ubiquity: Rand Water 1903-2003, pp. 226-233. 